\title{
Correlation between Personal Hygiene, Household Hygiene, and Atopic Dermatitis in Elementary School Children in Indonesia
}

\author{
Muhammad Ikhfa Yusril Bahari, ${ }^{1}$ Deryne Anggia Paramita ${ }^{2}$ \\ ${ }^{1}$ Faculty of Medicine, Universitas Sumatera Utara, Medan, Indonesia, ${ }^{2}$ Department of Dermatology \\ and Venerology, Faculty of Medicine, Universitas Sumatera Utara, Medan, Indonesia
}

\begin{abstract}
Atopic dermatitis is a chronic inflammatory skin disease characterized by persistent itching and reddening of the skin. In general, infants and children are more susceptible to atopic dermatitis. Many factors are associated with atopic dermatitis, one of which is personal hygiene. Personal hygiene is a condition or practice to maintain or improve personal health by keeping the body and the environment clean. Personal hygiene can influence the surrounding environment, such as by influencing the household hygiene. The purpose of this study was to determine the correlation between personal hygiene, household hygiene, and atopic dermatitis incidence among children who attended Pertiwi Elementary School Medan. This was a cross-sectional study with correlational analysis designed conducted at Pertiwi Elementary School Medan from July to December 2019. Data were collected using a questionnaire and analyzed using the Chi-Square test with $\mathrm{p}=0.05$ considered significant. Results showed that 28 children (39.4\%) had atopic dermatitis, with more girls affected than boys ( $n=19,67.9 \%$ vs. $n=9,32.1 \%$ ). The overall household hygiene and cleanliness were good. There is a significant relationship between personal hygiene, household cleanliness, and the incidence of atopic dermatitis $(\mathrm{p}<0.05)$.
\end{abstract}

Key words: Atopic dermatitis, household hygiene, personal hygiene

\section{Hubungan Personal Hygiene, Rumah Tangga, dan Dermatitis Atopik pada Anak Sekolah Dasar di Indonesia}

\begin{abstract}
Abstrak
Dermatitis atopik merupakan suatu penyakit radang kulit kronis yang ditandai dengan munculnya rasa gatal secara terus-menerus dan timbul ruam kulit yang memerah. Pada umumnya bayi dan anak-anak yang lebih rentan terhadap dermatitis atopik. Faktor-faktor yang dikaitkan dengan dermatitis atopik ini salah satunya yaitu personal hygiene. Personal hygiene adalah kondisi atau praktik yang digunakan orang menjaga atau meningkatkan kesehatan dengan menjaga diri mereka dan lingkungan mereka bersih. Faktor ini dapat mempengaruhi berbagai cakupan yang lebih luas seperti dalam kehidupan rumah tangga. Penelitian ini bertujuan mengetahui hubungan personal hygiene dan tingkat kebersihan dalam rumah tangga dengan kejadian dermatitis atopik pada anakanak di SD Swasta Pertiwi, Medan. Penelitian ini menggunakan desain analitik korelasi dengan pendekatan cross-sectional yang dilaksanakan di SD Swasta Pertiwi Medan dari bulan Juli-Desember 2019. Pengumpulan data dilakukan menggunakan kuesioner dan dianalisis dengan uji chi-square dengan $\mathrm{p}=0.05$ dianggap bermakna. Pada penelitian didapatkan hasil sebanyak 28 orang menderita dermatitis atopik lebih banyak perempuan 19 orang $(32,1 \%)$ dibanding dengan pria 9 orang $(67,9 \%)$. Hasil penelitian bahwa personal hygiene dan kebersihan dalam rumah tangga secara keseluruhan dikategorikan baik. Terdapat hubungan antara personal hygiene dan kebersihan dalam rumah tangga dengan kejadian dermatitis atopik $(\mathrm{p}<0.05)$.
\end{abstract}

Kata kunci: Dermatitis atopik, kebersihan rumah tangga, personal hygiene

Corresponding Author: Deryne Anggia Paramita, Department of Dermatology and Venereology, Faculty of Medicine, Universitas Sumatera Utara. Jalan dr. Mansyur No. 5, Medan, North Sumatera. Indonesia, Email: deryne.anggia@usu.ac.id 


\section{Introduction}

Atopic dermatitis (AD) is a chronic inflammatory skin condition, which includes severe pruritus, xerosis, and visible eczematous skin lesions that mainly begin early in life. While the interplay between individual genetic predisposition and environmental factors contributes to the development of $\mathrm{AD}$, the recent increase in the prevalence of $\mathrm{AD}$ might be attributed to increased exposures to various environmental factors rather than alterations in human genome. ${ }^{1}$

Manifestation of $\mathrm{AD}$ and place of predilection differ in the infant phase (2 months- 2 years), child phase (2-12 years), and adult phase (12 years-adulthood). ${ }^{2}$ Atopic dermatitis is also one of the most common skin diseases, with a prevalence of up to $25 \%$ in children and $2-5 \%$ in adolescents. The global adult prevalence of $\mathrm{AD}$, which is often severe, is estimated at $1-3 \%{ }^{3}$

Based on data obtained from the Kampar District Health Office in 2014, the atopic dermatitis incidence was ranked 10th among the most frequent diseases with 5,868 patients (2.27\%). In the year after 2014, atopic dermatitis was out of the top ten diseases, but the number of cases increased. ${ }^{4}$ Data from the Dermatology and Venerology Immunology Allergy Division of Dr. Soetomo General Hospital in Surabaya demonstrated that the number of $\mathrm{AD}$ patients visiting the hospital in 2009-2011 was 353 patients. ${ }^{5}$

The hygiene hypothesis as a primary explanation for the pathogenesis of atopic dermatitis suggested that hygiene plays a critical role in it. ${ }^{2}$

This study aimed to determine the relationship between personal hygiene, household hygiene, and the incidence of atopic dermatitis in Pertiwi Elementary School children, Medan. The other objective was to discover the proportion of AD, personal hygiene, and household hygiene levels among Pertiwi Elementary School children aged 6-7 years and their family.

It is expected that this study can provide accurate and trustworthy information to the public regarding the importance of maintaining personal and household hygiene against the incidence of $\mathrm{AD}$.

\section{Methods}

This was a cross-sectional correlation analysis involving all grade 1 and grade 2 students of Pertiwi Elementary School, Medan, Indonesia whose age were between 6-7 years old. This study was conducted from July to December 2019 with the approval from the Health Research Ethical Committee, Faculty of Medicine, North Sumatera University under the ethical clearance No. 52/TGL/KEPK FK USU-RSUP HAM/2019.

After the calculation on the required sample size was performed using the sample size formula, seventy-one subjects were sampled consecutively based on the inclusion criteria, i.e. children aged 6-7 years old whose parents signed the informed consent for participating in this study. Children were excluded if they suffered from skin diseases such as psoriasis, scabies, impetigo, urticaria, et cetera.

The instrument used in this study was the ISAAC questionnaire to determine the $A D$ status, and the personal and household hygiene questionnaire that had been tested for validation and reliability using the Statistical Package for the Social Sciences and discussions with relevant experts and specialists. The scoring for each item in the questionnaire ranged from 0 to 9 , with zero being the lowest score. Good personal and household hygiene was defined as a total score of $>75 \%$, while those who had a total score of $\leq 75 \%$ were defined as having poor personal and household hygiene. The questionnaire was distributed to the subject's parents and the parents filled out the questionnaire with the help from the research assistance.

\section{Results}

From the data collected it was revealed that 28 of 70 children who participated in this study suffered from atopic dermatitis. The distribution of the disease by gender is presented in the table below.

Based on the above table, it can be identified that the incidence of atopic dermatitis was higher in girls than in boys with 19 girls (67.9\%) versus nine boys (32.1\%).

The results showed that the proportion of respondents with good skin hygiene and not suffering from atopic dermatitis was $65.1 \%$ while those with good skin hygiene and suffering from atopic dermatitis was $89.3 \%$. Meanwhile, the proportion of the respondents with poor skin hygiene and suffering from atopic dermatitis was $10.7 \%$ while $34.9 \%$ had poor skin hygiene and not suffering from atopic dermatitis. When data were analyzed using the chi-square test, the $\mathrm{X} 2$ value was found to be 5.234 with $\mathrm{p}=$ 0.02 , showing that the respondents' behavior 
MIY Bahari and DA Paramita: Correlation between Personal Hygiene, Household Hygiene, and Atopic Dermatitis in Elementary School Children in Indonesia

Table 1 Frequency Distribution of Atopic Dermatitis by Gender

\begin{tabular}{lccccccc}
\hline & \multicolumn{4}{c}{ Atopic Dermatitis } & \multicolumn{2}{c}{ Total } \\
\cline { 2 - 7 } & \multicolumn{3}{c}{ Sex } & \multicolumn{3}{c}{ Yes } & \multicolumn{2}{c}{ No } & \multicolumn{2}{c}{} \\
\cline { 2 - 7 } & $\mathbf{( n = 2 8 )}$ & $\mathbf{\%}$ & $\mathbf{( n = 4 3 )}$ & $\mathbf{\%}$ & $\mathbf{( n = 7 1 )}$ & \% \\
\hline Male & 9 & $32.1 \%$ & 24 & $55.8 \%$ & 33 & $46.5 \%$ \\
Female & 19 & $67.9 \%$ & 19 & $44.2 \%$ & 38 & $53.5 \%$ \\
\hline
\end{tabular}

regarding skin hygiene significantly related to atopic dermatitis incidence in children in Pertiwi Elementary School Medan, Indonesia.

When seen from the perspective of good hand and nail hygiene, it was revealed that the proportion of respondents with good hand and nail hygiene and not suffering from atopic dermatitis was $65.8 \%$ and those with good hand and nail hygiene and suffering from atopic dermatitis was $92.9 \%$. Meanwhile, the proportion of respondents with poor hand and nail hygiene and suffering from atopic dermatitis was $7.1 \%$, while $44.2 \%$ had poor hand and nail hygiene and not suffering from atopic dermatitis.
Results of the chi-square test presented an X2 value of $11,172(p=0.001)$, indicating that the respondents' hand and nail hygiene significantly correlated with the atopic dermatitis incidence in children in Pertiwi Elementary School, Medan, Indonesia.

In terms of the relationship between the clothing hygiene and atopic dermatitis, this study demonstrated the proportion of respondents with good clothing hygiene and not suffering from atopic dermatitis of $58.1 \%$ while $85.7 \%$ had good clothing hygiene and suffering from atopic dermatitis. Meanwhile, poor clothing hygiene and suffering from atopic dermatitis was

Table 2 Cross Tabulation of Personal and Household Hygiene Level with Atopic Dermatitis

\begin{tabular}{|c|c|c|c|c|c|c|}
\hline \multirow{3}{*}{ Personal and Household Hygiene } & \multicolumn{4}{|c|}{ Atopic Dermatitis } & \multirow{3}{*}{$\mathbf{X}^{2}$} & \multirow{3}{*}{ P-value } \\
\hline & \multicolumn{2}{|c|}{ Yes } & \multicolumn{2}{|c|}{ No } & & \\
\hline & $\mathbf{n}$ & $\%$ & $\mathbf{n}$ & $\%$ & & \\
\hline \multicolumn{7}{|l|}{ Skin Hygiene } \\
\hline Good & 25 & $89.3 \%$ & 28 & $65.1 \%$ & \multirow{2}{*}{5,234} & \multirow{2}{*}{$0.02^{*}$} \\
\hline Poor & 3 & $10.7 \%$ & 15 & $34.9 \%$ & & \\
\hline \multicolumn{7}{|l|}{ Hand and Nail Hygiene } \\
\hline Good & 26 & $92.9 \%$ & 24 & $55.8 \%$ & \multirow[b]{2}{*}{11.172} & \multirow[b]{2}{*}{$0.001^{*}$} \\
\hline Poor & 2 & $7.1 \%$ & 19 & $44.2 \%$ & & \\
\hline \multicolumn{7}{|l|}{ Cleanliness of clothes } \\
\hline Good & 24 & $85.7 \%$ & 25 & $58.1 \%$ & \multirow[b]{2}{*}{6.030} & \multirow[b]{2}{*}{$0.014^{*}$} \\
\hline Poor & 4 & $14.3 \%$ & 18 & $41.9 \%$ & & \\
\hline \multicolumn{7}{|l|}{ Cleanliness of towels } \\
\hline Good & 26 & $92.9 \%$ & 30 & $69.8 \%$ & \multirow[b]{2}{*}{5.426} & \multirow[b]{2}{*}{$0.020^{*}$} \\
\hline Poor & 2 & $7.1 \%$ & 13 & $30.2 \%$ & & \\
\hline \multicolumn{7}{|l|}{ Cleanliness of beds and bed linen } \\
\hline Good & 25 & $89.3 \%$ & 29 & $67.4 \%$ & \multirow[b]{2}{*}{4.443} & \multirow[b]{2}{*}{$0.035^{*}$} \\
\hline Poor & 3 & $10.7 \%$ & 14 & $32.6 \%$ & & \\
\hline \multicolumn{7}{|l|}{ Cleanliness in the household } \\
\hline Good & 25 & $89.3 \%$ & 27 & $62.8 \%$ & \multirow[b]{2}{*}{6.074} & \multirow[b]{2}{*}{$0.014^{*}$} \\
\hline Poor & 3 & $10.7 \%$ & 16 & $37.2 \%$ & & \\
\hline
\end{tabular}

*) Significant on $\alpha<0.05$ 
seen in $14.3 \%$ respondents and poor clothing hygiene and not suffering from atopic dermatitis was identified in $41.9 \%$. Based on the chi-square test, the X2 value was found to be 6.030 ( $p=$ 0.014 ), indicating that the respondents' behavior in terms of the cleanliness of their clothes had a significant relationship with atopic dermatitis incidence in children in Pertiwi Elementary School, Medan, Indonesia.

A significant relationship between towel hygiene and atopic dermatitis incidence was also identified $(X 2=5.426 ; p=0.020)$. The proportion of respondents with good towel hygiene and not suffering from atopic dermatitis was $69.8 \%$ and those with good towel hygiene and suffering from atopic dermatitis was $92.9 \%$. Meanwhile, the proportion of respondents with poor towel hygiene and suffering from atopic dermatitis those with poor cleanliness of towels and not suffering from atopic dermatitis were $7.1 \%$, and $30.2 \%$, respectively.

Another significant relationship was also identified between the cleanliness of beds and bedsheets and atopic dermatitis incidence with a chi-square test result of $\mathrm{X} 2=4.443(\mathrm{p}=0.035)$. The proportion of children with good cleanliness of bed and bed linen and not suffering from atopic dermatitis was $67.4 \%$ and those with good cleanliness of bed and bed linen and suffering from atopic dermatitis was 89.3\%. Furthermore, there were $10.7 \%$ of respondents with poor cleanliness of bed and bedsheets and suffering from atopic dermatitis, while $32.6 \%$ had poor cleanliness of bed and bedsheets and not suffering from atopic dermatitis.

When analyzed from the perspective of the overall household hygiene, the majority of the respondents (89.3\%) had good hygiene in a household and suffering from atopic dermatitis, while more than half had good hygiene in a household and not suffering from atopic dermatitis reached more than half (62.8\%). Only a small number of respondents had poor household hygiene and suffering from atopic dermatitis (10.7\%) and $37.2 \%$ had poor household hygiene and not suffering from atopic dermatitis. Based on the chi-square test result of $\mathrm{X} 2=6.074(\mathrm{p}=0.014)$ shows that the respondents' behavior on household hygiene had a significant relationship with the atopic dermatitis incidence.

\section{Discussion}

Atopic dermatitis is a type of inflammatory skin disease that disrupts the skin barrier and its ability to retain moisture and is the most common disease found in children. From 71 samples obtained, it was discovered that as many as 28 children were affected by atopic dermatitis with more girls had atopic dermatitis than boys $(\mathrm{n}=19,67.9 \%)$. This is in line with Eichenfield et al. in 2014 who stated that women are more susceptible to atopic dermatitis than men with a ratio of $1.5: 1 .^{6}$ This is also strengthened by findings of a study in India conducted by Kumar et al. in 2014 that described the atopic dermatitis are more widely suffered by and found in girls than in boys. ${ }^{7}$

Personal hygiene is a way of human selfcare to avoid various exposures that may cause disease. From this understanding, it is said that the better a person's hygiene is, the higher the risk for atopic dermatitis. Personal hygiene assessed in this study were based on the daily habits in maintaining skin hygiene, hand and nail hygiene, cleanliness of towels, and cleanliness of beds and bed linen, which was then contrasted against atopic dermatitis. Results were then divided into two categories, namely the good and poor category. It was demonstrated that most respondents were in the good category in terms of their habits in maintaining personal hygiene, which includes skin hygiene, hand and nail hygiene, clothing hygiene, cleanliness of towel, and cleanliness of beds and bedsheets.

A significant relationship was identified between personal hygiene, which includes cleanliness of skin, hand and nail hygiene, cleanliness of clothes, cleanliness of towels, and cleanliness of beds and bedsheets, and the incidence of atopic dermatitis. This study correlates to the ALSPAC study that suggests a higher level of personal hygiene are associated with a $4 \%$ increase in the risk of AD. ${ }^{8}$ Furthermore, it is also in line with David Strachan's opinion concerning the hygiene hypothesis, where it is said the less exposure to the source of disease caused by a condition where the person is too clean and maintains the cleanliness too well, leading them to be more susceptible to allergies, including Atopic Dermatitis. ${ }^{9}$

Cleanliness in the household constitutes behaviors to maintain cleanliness at home that includes several aspects, such as the cleanliness of floor, bathroom, kitchen, and furniture inside the house. Household hygiene assessed in this study is the frequency respondents cleaning their house floor, bathroom, kitchen, and furniture, which then analyzed against the incidence of atopic dermatitis. The household hygiene was then categorized into good and poor categories. 
Based on the study's results, it was discovered that the frequency level of people in the house who can clean the floor, bathroom, kitchen, and furniture in the house is in a good category.

Based on the results of the chi-square test, a significant relationship between household hygiene, which includes the frequency level of people in the house who can clean the floor, bathroom, kitchen, and furniture in the respondent's home with atopic dermatitis, was discovered. This result can conclude that high hygiene scores may reflect a difference in behavior that would reduce exposure to infectious agents. The increased risk of atopy in hygienic children is in line with the hypothesis that early exposure to infections somehow protects against allergies in later life. ${ }^{10}$

It is concluded that 7-year-old girls suffer more from atopic dermatitis. The personal hygiene and cleanliness in households in the studied is good and a significant relationship is seen between personal and household hygiene and atopic dermatitis incidence.

\section{References}

1. Kim K. Influences of environmental chemicals on atopic dermatitis. Toxicological Res. 2015:31(2): 89-96.

2. Habif TP, Campbell J, Dinulos JGH, Chapman MS, Zug KA. Atopic dermatitis. Skin disease: diagnosis and treatment, $4^{\text {th }}$ ed. Philadelphia: Elsevier; 2017. p. 74.

3. Barroso B, Vera-Berrios RN, Rial JM, FariñaSabaris MC, Santos LC, Sastre J. Prevalence of severe atopic dermatitis in adults and children in a health area of Madrid, Spain. J Investig Allergol Clin Immunol. 2019;29(1):77-9.

4. Alini, Sinaga R. Faktor-faktor yang berhubungan dengan kejadian dermatitis atopik di Puskesmas Bangkinang Kota. Jurnal Kesehatan Masyarakat. 2018:2(2):33-42.

5. Herwanto N, Hutomo M. Studi Retrospektif : penatalaksanaan dermatitis atopik. Berkala Ilmu Kesehatan Kulit dan Kelamin. 2016: 28(1):8-17.

6. Eichenfield LF, Tom WL, Berger TG, Krol A, Paller AS, Schwarzenberger $K$, et al. Guidelines of care for the management of atopic dermatitis: section 2. Management and treatment of atopic dermatitis with topical therapies. J Am Acad Dermatol. 2014;71(1):116-32.

7. Kumar MK, Singh PK, Patel PK. Clinicoimmunological profile and their correlation with severity of atopic dermatitis in Eastern Indian children. J Nat Sci Biol Med. 2014;5(1):95-100.

8. Dickman M, Dawson AL, Dellavalle RP. The relationship between hygiene and microbial burden in atopic dermatitis risk based on a systematic review. Arch Dermatol. 2012;148(8):936-8.

9. Scudellari M. Cleaning up the hygiene hypothesis. PNAS. 2017:114(7):1433-6.

10. Sherrif A, Golding J, ALSPAC Study Team. Hygiene levels in a contemporary population cohort are associated with wheezing and atopic eczema in preschool infants. Arch Dis Child. 2002;87:26-9. 